\title{
Spatial Distribution of Conventional Air Pollutant and GHGs from Land Transportation in Two Developing Cities and Main Co- Benefit Actions For Reducing It.
}

\author{
Haryono S Huboyo ${ }^{1,2^{*}}$, Endro Sutrisno ${ }^{1}$, Ana M Sutrisno ${ }^{1}$, Velida L Tiarani ${ }^{1}$ \\ ${ }^{1}$ Department of Environmental Engineering, Faculty of Engineering, Diponegoro University, Semarang - Indonesia \\ ${ }^{2}$ Center for Environmental Studies, Diponegoro University, Semarang - Indonesia
}

\begin{abstract}
Surakarta and Yogyakarta are the emerging cities which now struggle to manage its pollution from transport sector. This study aims to calculate the emission, to describe spatial distribution and to analyze existing co-benefit actions related to land transportation in Surakarta and Yogyakarta in 2015. The main method used for this analysis comes from Ministry of Environment and Forestry. The VKT values were aggregated for Surakarta city and Yogyakarta city and it showed $27.36 \mathrm{~km} / \mathrm{day}, 37.52 \mathrm{~km} /$ day and $27.71 \mathrm{~km} /$ day for motorcycle, car and truck respectively. At Surakarta city, the emission load from transport sector in 2014 were 449.95 tons/ year (TSP), 5134 ton/ year(NOx), 243 ton/year $\left(\mathrm{SO}_{2}\right), 50,605$ ton /year $(\mathrm{CO})$ and 421,594 tons/year $\left(\mathrm{CO}_{2} \mathrm{e}\right)$. Villages of Kemlayan, Timuran and Keprabon showed the highest emission. While in Yogyakarta city in 2014, the burden of TSP was 58,409 tons/year, NOx was 8,058 tons/year, $\mathrm{SO}_{2}$ was 285.37 ton/year, $\mathrm{CO}$ was 75,008 tons/year and $\mathrm{CO}_{2} \mathrm{e}$ by 601,068 tons/year. The village of Pringgokusuman and Sosromeduran showed the highest emission. Several programs were adopted in Yogyakarta city and Surakarta city for mitigating air pollution i.e ITS-ATCS, BRT system, car free day.
\end{abstract}

\section{Introduction}

Vehicle emission is considered to be major emission of conventional air pollutants as well as greenhouse gases (GHGs) particularly in urban cities [1]. Carbon dioxide $\left(\mathrm{CO}_{2}\right)$, methane $\left(\mathrm{CH}_{4}\right)$ and nitrous oxide $\left(\mathrm{N}_{2} \mathrm{O}\right)$ are the major of GHGs. Conventional air pollutants such as particulate matters $\left(\mathrm{PM}_{2.5}, \mathrm{PM}_{10}\right), \mathrm{SO}_{2}, \mathrm{NO}_{2}, \mathrm{VOCs}$, ground level $\mathrm{O}_{3}$ are blamed for numerous health impacts if we related to the human exposure. Moreover fine particulate matter $\left(\mathrm{PM}_{2.5}\right)$ and ozone are the main contributor of human health problem from transport sector [2]. Health effects related to traffic sources emission has been broadly studied and summarized by HEI [3].

Emission from transport sector could be governed by engine combustion technology, sort-quality of consumed fuel, exhaust device control, sort of road surface-terrain and vehicle operation. These factors could play simultaneously for worsening the emission.

Air pollution emission inventory in urban area needs a robust vehicle population estimation [4]. To find the real number of operational vehicles in the road is a big challenge as it requires intensive and broad sampling in the field. Two methods are generally used for conducting emission inventory i.e top-down and bottom-up method. Several studies adopted these methods for estimating air pollution load in emission inventory [5-7].
Both of these methods have advantages and disadvantages so that selecting the method use depend on the availability resources and time allocation.

Big urban cities in Indonesia now are struggling with traffic jam, congestion and huge emitted air pollution related to transportation sector. Private vehicles growth is much higher than public transport means. Therefore, several policies were adopted to lessen this emission. These policies-related to reduction of air pollution are Intelligent Transportation System (ITS), implementing Traffic Impact Control, introducing Bus Rapid Transport (BRT) system, developing non-motorized transport, renewing paratransit public transportation and introducing smart driving training. These measures usually are not well prepared for reduction calculation methodology. This study is addressed to know the emission load through emission inventory from transport sector at two cities in Indonesia.

\section{Methodologies}

This research was conducted at two cities i.e Surakarta city at Central Java Province and Yogyakarta city in Special Province of Yogyakarta (See Fig.1). We collected data on June to September 2015. For calculating the emission we collected secondary data (registered vehicle number, main road length, road network) from local government agency related to transport sector and state-owned oil and gas company 
(Pertamina) for knowing the oil consumption. Based on these secondary data, we derived the vehicle kilometer travelled (VKT) either for line source and area source. Actual data on odometer for each vehicle on year basis were also gathered from several vehicle repairing workshops.

For estimating the spatial distribution, we gridded the city every $500 \mathrm{~m}$ length. The calculation for each grid follows this formula:

$$
\text { VKT b,c,k }=\left(\mathrm{K}_{1}{ }^{\mathrm{k}}+\mathrm{K}_{2}{ }^{\mathrm{k}}\right) \times \mathrm{VKT} \text { b,c }
$$
where:

VKT $b, c, k=$ VKT for vehicle $b$ category using c fuel at grid $\mathrm{k}$

VKT $b, c=$ VKT for vehicle $b$ category using c fuel $\mathrm{K}_{1}{ }^{\mathrm{k}}=\frac{\alpha \mathrm{pk}}{\mathrm{pt}}=$ weighing for population density

$\mathrm{K}_{2}{ }^{\mathrm{k}}=\frac{(1-\alpha) \mathrm{Lk}}{\mathrm{Lt}}=$ weighing for road area network

$\mathrm{pk}=$ population number at grid $\mathrm{k}, \mathrm{pt}=$ total population, $\mathrm{Lk}=$ road area at grid $\mathrm{k}, \mathrm{Lt}=$ total area of road,

$\alpha=$ facktor (in fraction $0-1$ ) which define population and road area affecting VKT. For Indonesian case, the number is 0.35 .

In order to know the vehicle emissions, we adopted several secondary emission factor [8-10]. Overall the method we used for estimating the emission at city basis is derived from Ministry of Environment and Forestry [11].

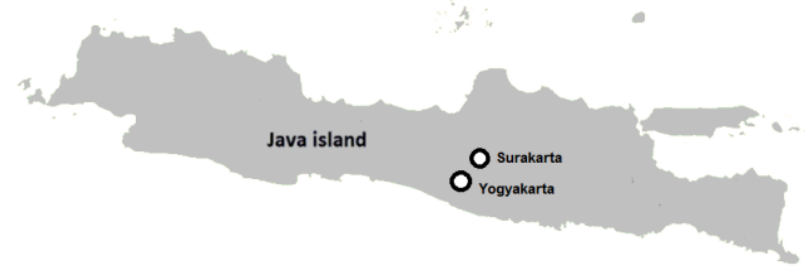

Fig. 1. Location of the Study

\section{Results and Discussion}

\subsection{Vehicle Number and VKT}

The first step to quantify the emission related to transport sector is determining the VKT. This method corresponds to bottom-up method. The VKT could be derived from volume number of vehicles passing through the main road combined road length. The VKT at main road (VKT Line Sources) and VKT for road network (VKT Area Sources) are depicted at Fig.2. From the Fig.2 it is clearly seen that the VKT between Surakarta and Yogyakarta is comparable for area sources. However it differs for VKT line sources. It could be caused by method for selecting the road. For motorcycle and bus, it showed comparable, while for car and it was quite different. The registered number of car for two cities were comparable at 2014, while for motorcycle the registered number at Yogya city is little bit higher than those at Surakarta city. The number of bus at Surakarta city was three times than those at at Yogyakarta city in 2014.
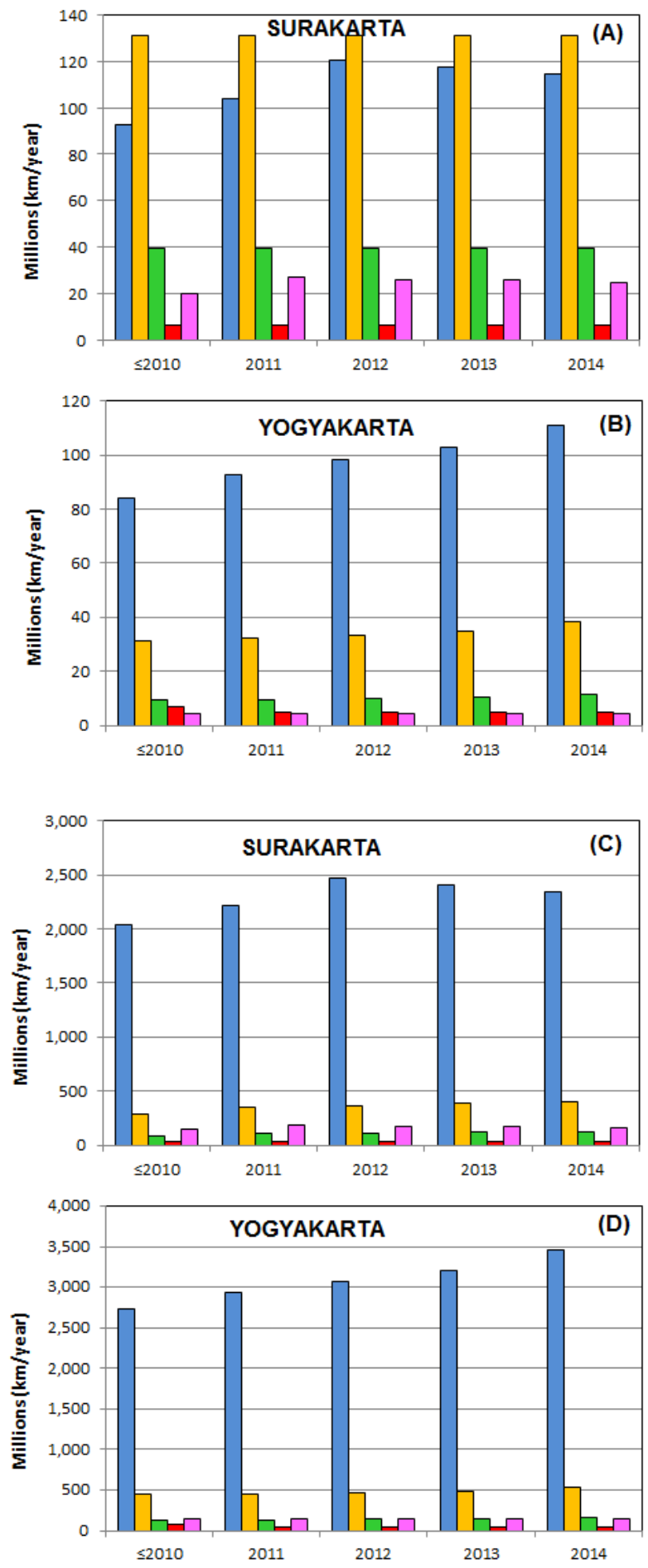

$\square$ Motorcycle $\square$ Gasoline car $\square$ Diesel car $\square$ Bus $\square$ Truck

$\begin{array}{ll}\text { A. } & \text { VKT Line Sources (Surakarta) } \\ \text { B. } & \text { VKT Line Sources (Yogyakarta) } \\ \text { C. } & \text { VKT Area Sources (Surakarta) } \\ \text { D. } & \text { VKT Area Sources (Yogyakarta) }\end{array}$

Fig. 2. VKT for each vehicle mode

\subsection{Emission Load}

The VKT total (line and area sources) was used to quantify the emission load. The result of emission load 
(ton/year) is listed in Table 1. Based on the calculation results, the biggest contributor for air pollution for both cities was motorcycle. At Surakarta city, motorcycle contributes $62 \%, 88 \%, 65 \%, 48 \%$ for TSP, $\mathrm{HC}, \mathrm{CO}$ and $\mathrm{CO} 2 \mathrm{e}$ respectively. While at Yogyakarta city motorcycle contributes $73 \%, 89 \%, 67 \%, 51 \%$ for TSP, $\mathrm{HC}, \mathrm{CO}$ and $\mathrm{CO} 2 \mathrm{e}$ respectively. The biggest contributor of NOx and $\mathrm{SO} 2$ was truck both in Surakarta and Yogyakarta city. It showed more than $50 \%$ in Surakarta city and around 30 - 40\% in Yogyakarta city. The least contributor for air pollution was bus. The biggest emission load of bus was for $\mathrm{SO} 2$ parameter. It contributes $12-16 \%$ of $\mathrm{SO} 2$ emission. The other parameter (TSP, NOx, HC, CO, $\mathrm{CO} 2 \mathrm{e}$ ) were contributed by bus less than $8 \%$. This indicates that public transport is the preferable for reducing air pollutants related to transport sector.

Table.2 Emission load of air pollutant (ton/year)

\begin{tabular}{|c|c|c|c|c|c|}
\hline Parameter & MC & GC & DC & Bus & Truck \\
\hline \multicolumn{6}{|c|}{ Surakarta city } \\
\hline TSP & 281.15 & 1.97 & 31.2 & 21.14 & 114.49 \\
\hline NOX & 679.45 & 788.44 & 412.14 & 359.42 & 2895 \\
\hline SO2 & 18.74 & 10.25 & 51.81 & 28.09 & 134.11 \\
\hline HC & 13823 & 1577 & 23.55 & 39.26 & 294.39 \\
\hline CO & 32801 & 15769 & 329.71 & 332.23 & 1374 \\
\hline CO2 E & 202889 & 110969 & 37872 & 19485 & 50379 \\
\hline \multicolumn{5}{|c|}{ Yogyakarta city } \\
\hline TSP & 42804 & 285 & 4514 & 334 & 10472 \\
\hline NOX & 1034 & 1141 & 2667 & 568 & 2648 \\
\hline SO2 & 2854 & 1483 & 7495 & 4437 & 12268 \\
\hline HC & 21046 & 2281 & 34.07 & 62.03 & 269.29 \\
\hline CO & 49939 & 22811 & 476.96 & 524.83 & 1257 \\
\hline CO2 E & 308891 & 160527 & 54786 & 30781 & 46083 \\
\hline
\end{tabular}

MC: motorcycle, GC: gasoline car, DC: diesel car

\subsection{Spatial Emission Distribution}

To know the location which has high emission of air pollutant, we show the distribution of air pollutant based on gridded location for each city. In this paper we only show two parameters i.e TSP and CO2e. Overall, the spatial distribution for two cities are depicted in Fig.3 Fig.6.

From this figure, for Surakarta city Villages of Kemlayan, Timuran and Keprabon showed the highest emission. While in Yogyakarta city, the village of Pringgokusuman and Sosromeduran showed the highest emission. It should be noted that the emission we calculate here was derived from quantifying vehicle activity based on grid. Thus the location or grid which has high volume number of vehicle in the road will have high emission.

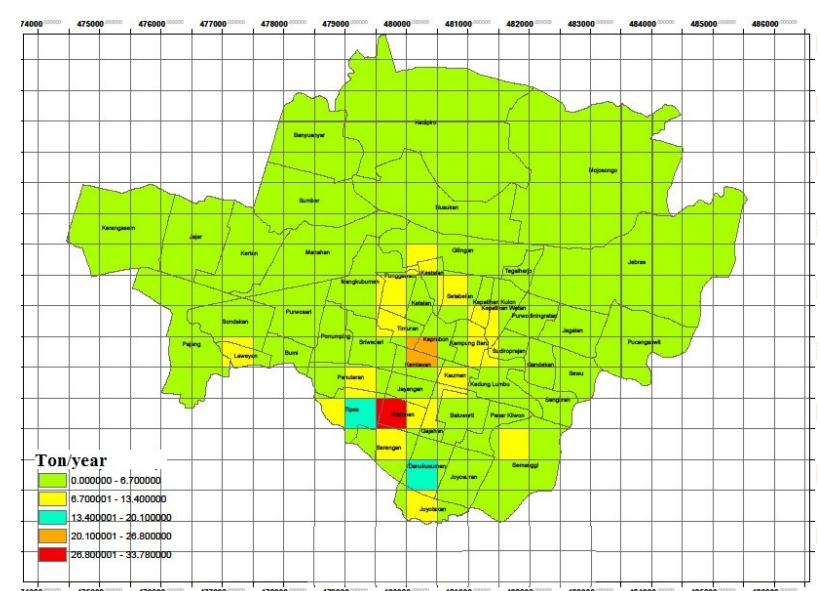

Fig.3. Spatial TSP distribution at Surakarta city

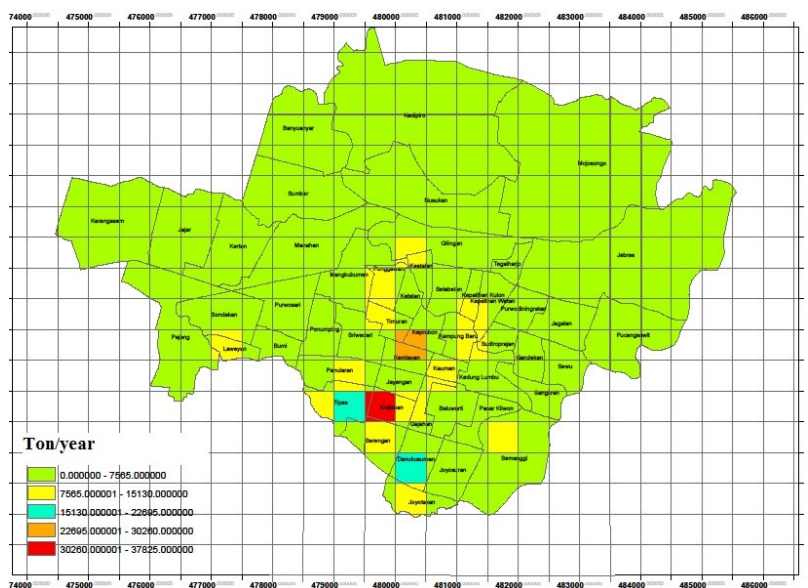

Fig.4. Spatial $\mathrm{CO} 2 \mathrm{e}$ distribution at Surakarta city

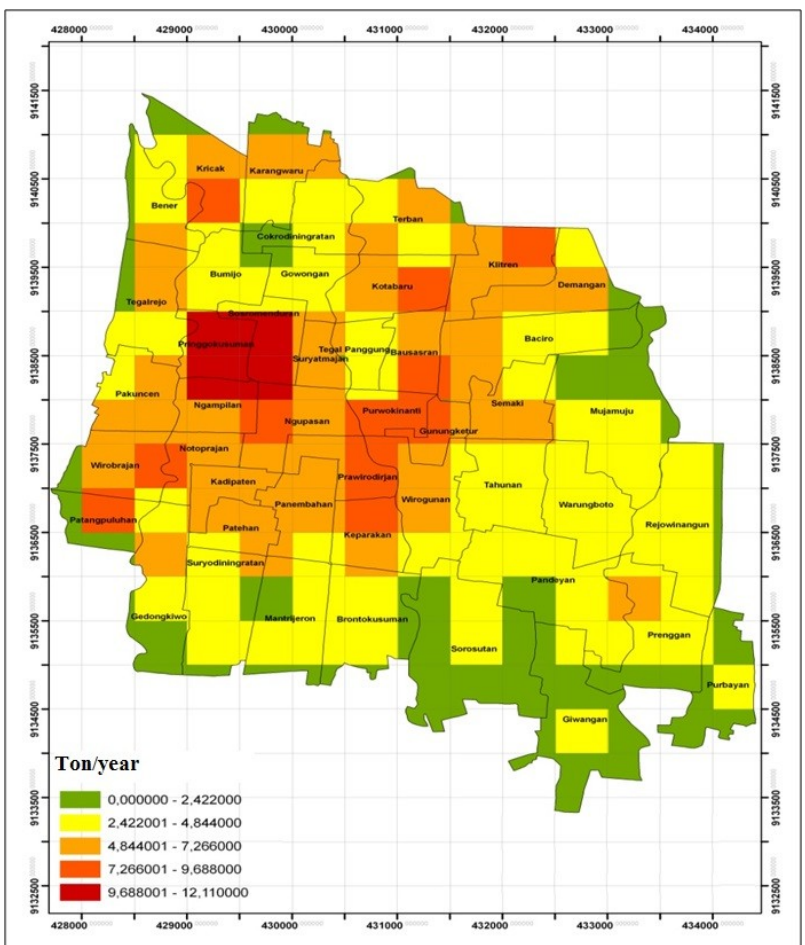

Fig.5. Spatial TSP distribution at Yogyakarta city 


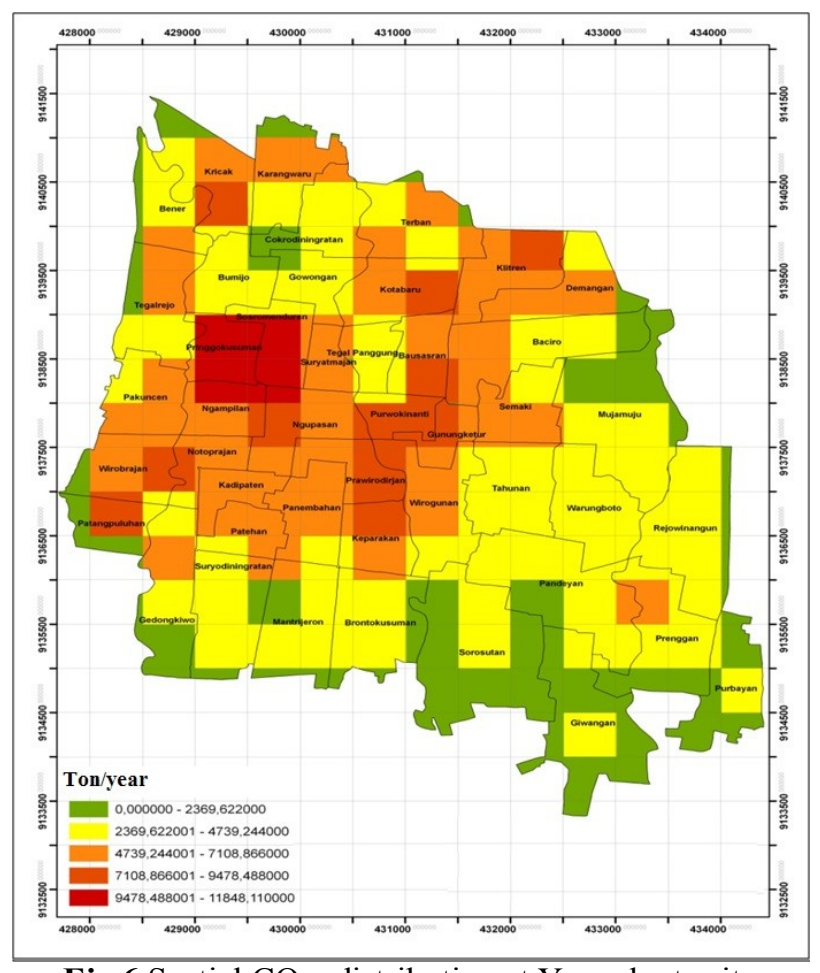

Fig.6 Spatial $\mathrm{CO}_{2} \mathrm{e}$ distribution at Yogyakarta city

\subsection{Emission Reduction Measures}

Using formula generated by Ministry of Transportation, we estimate the emission reduction of $\mathrm{CO}_{2} \mathrm{e}$ as a results of several measures i.e implementation of ATCS (area traffic control system), operational of bus rapid transit (BRT) and car free day (CFD). Based on our calculation the results of emission reduction of those measures are listed in Table.

Table 2. Emission Reduction After Measures Operation (ton/year)

\begin{tabular}{|l|c|c|}
\hline Measures & Surakarta & Yogyakarta \\
\hline ATCS & $3042(0.62 \%)$ & $4964(0.83 \%)$ \\
\hline BRT & $12795(2.6 \%)$ & $17596.6(2.93 \%)$ \\
\hline CFD & $1427(2.01 \%)$ & $440.97 \%(1.56 \%)$ \\
\hline
\end{tabular}

In Yogyakarta, other measures also be adopted such as park management, smart driving which could reduce GHGs emission 6262.28 ton/year (1.04\%) and 1229.5 $(0.2 \%)$ respectively.

\section{Conclusions}

Emission of air pollutants in urban area were estimated using bottom approach with VKT parameter. The VKT values were aggregated for Surakarta city and Yogyakarta city and it showed $27.36 \mathrm{~km} /$ day, 37.52 $\mathrm{km} /$ day and $27.71 \mathrm{~km} /$ day for motorcycle, car and truck respectively. At Surakarta city, the emission load from transport sector in 2014 were 449.95 tons/ year (TSP), 5134 ton/ year (NOx), 243 ton/year $\left(\mathrm{SO}_{2}\right), 50,605$ ton / year $(\mathrm{CO})$ and 421,594 tons/year $\left(\mathrm{CO}_{2} \mathrm{e}\right)$. Villages of Kemlayan, Timuran and Keprabon showed the highest emission. While in Yogyakarta city in 2014, the burden of TSP was 58,409 tons/year, NOx was 8,058 tons/year, $\mathrm{SO}_{2}$ was 285.37 ton/year, $\mathrm{CO}$ was 75,008 tons/year and $\mathrm{CO}_{2} \mathrm{e}$ by 601,068 tons/year. The village of Pringgokusuman and Sosromeduran showed the highest emission. Several programs were adopted in Yogyakarta city and Surakarta city for mitigating air pollution i.e ITS-ATCS, BRT system, car free day. However the reduction achievement was quite small compare to overall emission.

\section{Acknowledgment}

This study was supported by Cluster Research Group on Air Pollution Management in Environmental Engineering Department Diponegoro University.

\section{References}

1. K. Papagiannaki, D. Diakoulaki, Energy Policy; 37:3259-67 (2009)

2. C. Guerreiro, F. de Leeuw, F. \& V Foltescu. Air Quality in Europe: 2013 report. EEA report No. 9/2013. Luxembourg: Publications Office (2013).

3. Health Effects Institute. Traffic-Related Air Pollution: A critical review of the literature on emissions, exposure, and health effects. HEI special report 17. Boston, Mass.: Health Effects Institute (2010)

4. S. Soylu. Energy Policy.35:4088-94 (2007)

5. AG. Progiou, IC. Ziomas. Sci. Total Environ 410, 17 (2011)

6. HK. Wang, CH. Chen, C. Huang, LX Fu. Sci. Total Environ 398, 60-67 (2008)

7. R. Borge, I. de Miguel, D. de la Paz, J. Lumbreras, J. Perez, E Rodriguez. Atmos. Environ 62, 461-471 (2012)

8. IPCC. Guidelines for National Greenhouse Gas Inventories. Volume 2 : Energy (2006)

9. JICA. Study of Integrated Transportation Master Plan for Jabodetabek (SITRAM Phase II). (2014)

10. CORINAIR. Atmospheric Emission Inventory Guidebook 3th Edition. European Environment Agency (2006).

11. Kementerian Lingkungan Hidup dan Kehutanan. Pedoman Teknis Penyusunan Inventarisasi Emisi Pencemar Udara di Perkotaan. Jakarta (in Indonesian) (2013). 